\title{
Specific Learning Disorder in School: Clinical View of Parental Support on Student Reading Disabilities
}

\author{
Emilie Clarisse Tchokote \\ Department of Sciences of Education, Higher Teacher Training College (HTTC), University of Yaoundé I, Yaoundé, Cameroon
}

Email address:

emilietchoko@yahoo.fr

\section{To cite this article:}

Emilie Clarisse Tchokote. Specific Learning Disorder in School: Clinical View of Parental Support on Student Reading Disabilities. American Journal of Applied Psychology. Vol. 9, No. 6, 2020, pp. 160-165. doi: 10.11648/j.ajap.20200906.13

Received: October 27, 2020; Accepted: November 9, 2020; Published: November 19, 2020

\begin{abstract}
It is known that the specific learning disorder is linked to risk of school failure and emotional disturbance. The aim of this study is to grasp the clinical view of specific learning disorder and the incidence of parental support on the reading disabilities of students. Using the qualitative study approach, four school children (age included between 10 to 12) were selected in Government Bilingual Primary School (GBPS) at Kumba I council (Cameroon) base on eligibility criteria. The students have participated in this study with their parents. The semi-structured interview guide was used to collect data which were analyzed through the thematic content analysis. The result shows that the lack of parental support impacts on student's level of reading disabilities. This situation negatively affects the cognitive development of a student because, the construction of knowledge inevitably involves reading and writing. The significant link between parent-child's quality relationship and student's reading disability shows that peculiar importance should be given to family factors in such a context. In conclusion, this study highlights the importance of parental support of students and show how it can reduces difficulties in their academic performance. It can also reduce their psychological difficulties as anxiety, low self-esteem and other behavioral difficulties. There is a need of parental training session with collaboration of school community in such a context, to help parents identify the learning difficulties of their children and to be more psychologically supportive with their children.
\end{abstract}

Keywords: Learning Disorder, Parental Support, Reading Disability, Dyslexia, Student

\section{Introduction}

Learning disabilities are specific learning difficulties which affect skills such as speaking, listening, reading, spelling, reasoning, organizational skills and writing. According to Bender, its include profiles such as; dyslexia, dyspraxia, dysphasia, dyscalculia and dysorthographia [1]. But amongst them, dyslexia is the largest of this cohort, with approximately $80 \%$. Dyslexia is commonly appeared in the mild 1930s literature and refers to the dysfunctioning in the identification, as well as, the use and comprehension of writing words. It impacts on school achievement. It can't be diagnosed before school age and it's becomes very apparent by the age of eight years, when the child starts to integrate in reading textbooks.

Dyslexia is regarded as an academic difficulty but also it is a profile which affects emotional wellbeing of student because the experience of failure has a negative effect on the self- concept and self-esteem of children $[1,2]$.
In this same logic, Bonifacci et al study how rumination as cognitive process characterize by a repetitive thinking, negative feelings and thoughts affect the children with specific learning disorders and their parents [3].

It is an important issue in Cameroon context since; it limits possibility for the students at risk of dyslexia to reach plenitude of their cognitive, affective and creative capacity that UNICEF has specified as a major educational challenge of our society [4]. Dyslexia is currently encounter in primary school where students are supposed to learn and acquire reading and writing skills before reaching College, and some students arrive class five with this difficulty. More for those who reach college at one level are blocked because it is in primary school that reading skills are acquired. Thereby, certain students after many failures, drop out of school or simply abandon it. While, research show that dyslexic pupils are not lazy, they have normal IQ, they don't have impairment, but the part of their brain which is responsible of reading treatment such as right hemisphere is dysfunctional, 
making that they face difficulties to acquire reading skills.

The distinction between dyslexia and reading difficulties is extremely important to be made and all the children who face difficulties in reading are not necessary consider as dyslexic children. Although in practice, it is not always clear to distinguish clearly the clinical point of view of reading disability to dyslexia. This study will focus more on specific learning disorder, the case of reading disability as stated in the classification group of Neuro-developmental Disorders, by the Diagnostic and Statistical Manual of Mental disorders [5].

\section{Context of the Study}

Since more than one decade, Cameroon government struggles against illiteracy and willing that each child can benefit of free basic education. For that reason, the child can end primary school knowing how to read and write as first skills to acquire knowledge and competences. These skills will allow him to be as stipulate in guidance law of 14 of April 1998 in the article 5, a citizen deep-rooted in his culture but opened in the world, developed cognitively, emotionally and physically [6]. This educational policy concerns both children with learning difficulties and those without. Teaching methods as competences base- approach are used by teacher to help student reach this objective, taking in consideration students' differences and needs. Despite of government struggles, many students with reading disability evolve without coping with their difficulties.

Moreover, some parents acquire this governmental help as an occasion for them to abandon their responsibility in the education of their children. The school institution and the teachers however, need the collaboration and support of parents to help students who face learning disabilities, especially reading disabilities in order to reach the objective of guidance law. Vygotsky claims that the child is completely dependent on other people, especially the parents, who initiate the child's actions by instructing him as to what to do, how to do, as well as what not to do [7].

In fact it is observed that certain students who are reading disable, go to school every day where they struggle to read since class two, without having impairment and living with their parents, arrived nevertheless in form five without knowing to read. While, arrived at that level, a student must be able to read in order to solve the problem situations that will arise in the school context and prepare him next year for competitive common entrance and first school living certificate.

According to Vygotsky, it is in a linguistically and culturally rich environment that optimal child can easily develop his personality, through the activities carried out in interaction, exchange, work verbalization, co- development with others [8]. These elements help the child to better develop cognitively and he also needs interaction with parents to build his language [9]. The entry of the child in the scriptural world is the same as in the oral world. Indeed, the child develops his own representation of oral reading and writing through stories that adults read. Thus, if parents play their role and are involved in the acquisition of reading skills of their children, students at risk of reading disability can quickly cope with their difficulties rather than leave the whole responsibility to the teacher.

This study posits the problem of reading disability of student and the incidence of parental support in this context.

\section{The Role of Parent in the Situation of Learning Difficulties of Student: The Case of Reading Disability}

Certain authors as Dawson and Ashaman, Brazelton and Cramer, thought that a positive parent-child relationship provides the base of children's learning success, and the interaction between children and their parents help to drive their emotional, physical, and intellectual development. Particularly in the age of 6 to 11 years, self-esteem is closely related to school situations, [3, 10-13]. Development of the concept of self serves as a filter through which the child evaluates his behavior and that of others.

The harmonious parent-child relationship can permit to support the child on his efforts in the reading process by encouraging, motivating, accompanying him in his learning process. In this context, he can believe on his capacity to overcome his difficulty and effectively engaging himself to read. According to Senechal, parents can participate with their children in early literacy activities such as pointing, and naming objects, storytelling, and reading [14].

Bergin addresses the affective quality of the parent-child relationship during shared book reading with children [15]. Research has emphasized on the quality of parent-child reading with beginning readers. Parental behavior, occupational status will have important consequences for a child's development of specific cognitive skills, learning strategies, and personality characteristics.

\section{Methods}

The research design was based on qualitative method with multiple case study approach. The study was carried out in Government Bilingual Primary School (GBPS) at Kumba I council and focused on class five students as the target population. The eligibility criteria helped to specify the characteristics that subject must possess in order to be included in the study (to be a student, facing reading disability, leaving with his/her parent (s), age included between 10 and 12). Four students and their parents was chosen based on these eligibility criteria. The four selected cases are two boys and two girls. To respect ethic, some pseudonym were attributed to them as Cynthia, Paul, John and July.

The study used semi-structured interviews as technique of data collection with interview guides. These interview guides were created around the themes and sub themes related to sub-variables and indicators (identification of learning disorder, manifestation of reading disability, the parent-child 
relationship, existence or lack of parental support).

Data are recorded through the use of an audio recorder. But it required the prior permission of the participant and they freely signed the consent form. After the recording, the raw data are used for transcription. A coding scheme has been developed for the study in order to build a data analysis plan. The data was analyzed through a thematic content analysis that will be justified through the use of quotations, or specific statements coming from the participants. Data gathered from the interviews were analyzed for themes and indexed into analytical categories, a technique common to qualitative research [16].

\section{Findings}

\subsection{Presentation of Cases}

i. Case of Cynthia: Cynthia is a student in class five at GBPS-Group 1 Station-Kumba. She is an 11 years old girl living with her two parents (father and mother). She is the first child in the family of two children, she has one younger sister. Cynthia's mother and father are both farmers and they have to travel each time because of the distance between the house and the farm. The interview was carrying out on the mother who was available.

In fact, Cynthia repeated class three because of her reading difficulties, and the teacher informed the mother about it. She is facing phonological difficulty and she is classified amongst the "slow reader ". This is because she does not have good phonemic awareness, which impacts on her reading pace, taking more time than normal to associate phonemes (sounds), symbols and syllables (grapheme). When the letters or syllables are isolated, she is still trying to identify. In contrary, if two syllables are already combined, the task becomes more complicated for her.

ii. Case of Paul: Paul is a student in class five at GBPS-
Group 1 Station-Kumba. He is a 12 years old boy living with both parents. He is the second child in the family of three children. He has an elder brother who is in high school and a younger sister. Paul's mother is a farmer and the father is trader. The interview was carrying out only with the mother, because the father was absent. Paul repeated class three (03 times) and class five (02 times). He is disabling to recognize a word in a sentence, he confuses and reverses the letters and sequences of letters, for example instead of " $b$ ", he reads " $\mathrm{d}$ ". The reading disability is the type phonological and dysorthographia, for that reason Paul falls under the category of Bad reader."

iii. Case of John: John is a student in class five at GBPS Group I Station-Kumba. He is a 12 years old boy living with his parents (mother and father). He is the older child in a family of 3 children, and has 2 younger sisters. His mother is a farmer and his father is a butcher in the market. John repeated class five and has severe difficulties to read. He is a "slow reader" as he himself said: I read the syllables but when mixing the syllables I cannot read the word". Thus, associate syllables take him more than expected time and decreasing its read rate. Sometimes he repeats the syllables once or twice before reading the word.

iv. Case of July: July is a student in class five at GBPSGroup 1 Station-Kumba. She is a 12 years old girl living with her parents. She is a second child in a family of 5 children and her father is a farmer while her mother sells tomatoes in the market. July has not yet repeated a class. She faces reading and writing difficulties. She reads very slowly and takes more time on one syllable by repeating it before reading it, so she doesn't have phonemic awareness to distinguish the different sounds that make up spoken words or syllables.

Table 1. Summary table of the cases study.

\begin{tabular}{|c|c|c|c|c|c|}
\hline Cases & Age & Type of reading disability & Family situation & parental occupation & Observation \\
\hline Cynthia & 11 & $\begin{array}{l}\text {-phonological difficulty; } \\
\text { - "slow reader"; } \\
\text {-difficulty to associate phonemes (sound), symbols and syllables; } \\
\text { - repeat class three because of the reading difficulty. }\end{array}$ & $\begin{array}{l}-1^{\text {st }} \text { child in a family } \\
\text { of two; } \\
\text { - one younger sister. }\end{array}$ & $\begin{array}{l}\text {-mother and father are } \\
\text { farmers; } \\
\text {-parents travel each time } \\
\text { to go to their farm. }\end{array}$ & $\begin{array}{l}\text {-interview was carrying } \\
\text { out on the mother who } \\
\text { was available; } \\
\text { - father is always absent }\end{array}$ \\
\hline Paul & 12 & $\begin{array}{l}\text {-disable to recognize a word in a sentence; } \\
\text { - confuse, reverse the letters and sequences of letters (instead of } \\
\text { "b", he reads "d"); } \\
\text { - phonological difficulty and dysorthographia; } \\
\text { - "bad reader"; } \\
\text {-repeat class three ( } 03 \text { times) and class five ( } 02 \text { times). }\end{array}$ & $\begin{array}{l}2^{\text {nd }} \text { child in the } \\
\text { family of three; } \\
\text {-one elder brother } \\
\text { and one younger } \\
\text { sister. }\end{array}$ & $\begin{array}{l}\text {-mother is a farmer; } \\
\text {-father is a trader. }\end{array}$ & $\begin{array}{l}\text {-interview was carrying } \\
\text { out on the mother; } \\
\text {-father is absent. }\end{array}$ \\
\hline John & 12 & $\begin{array}{l}\text {-difficulty to read associate syllables; } \\
\text {-“slow reader"; } \\
\text {-repeat class five because of the reading difficulty. }\end{array}$ & $\begin{array}{l}-1^{\text {st }} \text { child in a family } \\
\text { of three; } \\
\text {-two younger } \\
\text { sisters. }\end{array}$ & $\begin{array}{l}\text {-mother is a farmer; } \\
\text {-father is a butcher }\end{array}$ & $\begin{array}{l}\text {-interview was carrying } \\
\text { out on the mother; } \\
\text {-father is absent. }\end{array}$ \\
\hline July & 12 & $\begin{array}{l}\text { reading difficulty and writing; } \\
\text { "slow reader"; } \\
\text { has not yet repeat class }\end{array}$ & $\begin{array}{l}2^{\text {nd }} \text { child in a family } \\
\text { of five. }\end{array}$ & $\begin{array}{l}\text { Father is a farmer; } \\
\text {-mother sells tomatoes }\end{array}$ & $\begin{array}{l}\text {-interview was carrying } \\
\text { out on the mother; } \\
\text { - father is absent. }\end{array}$ \\
\hline
\end{tabular}




\subsection{Reading Disabilities and His Incidence on Student}

Reading disability negatively affects the cognitive development of a student because the construction of knowledge inevitably involves reading and writing. The student with the reading disability can have more difficulty to succeed in his studies. Some of the participants failed on the class examination because of their reading disability as the case of Cynthia who repeated class three, Paul who repeated class three (03 times) and class five (02 times), John who repeated class five. This situation has a significant impact on other learning activities and lead to school failure.

As Alexander-passe, Mugnaini et al, and Kempe et al. show, students with reading disability in a classroom face several difficulties in their academic performance $[17,18,2]$. This situation can cause difficulties in social interaction as well as anxiety, low self-esteem and other behavioral difficulties. It is known that reading disability can be linked to externalizing and internalizing disorders such as attention deficit-hyperactivity disorder (ADHD), anxiety [18, 2, 19].

\subsection{Situation of Reading Disability and Incidence of Parental Support}

Reading and writing are the foundation on learning capacity [20]. Children with reading difficulties must be quickly diagnosed in order to solve the problem early and to avoid school failure. In this situation, teachers and the school community should put in place various strategies by implementing teaching methods, conductive learning and teaching approaches, and accompaniment of students who face various difficulties as reading difficulty. In addition to required support by the school community, the family has an important role to play in the sense that, the child comes back at home to exercise what has been taught in class by doing homework, revision etc. The family support passed through an appropriate communication, a good emotional support and an effective care of a child with reading disability.

Concerning the quality of communication, the participants face an inappropriate communication with their parents. The case of Cynthia shows that, her mother tries to communicate with her daughter although the type of communication is inappropriate to help her avoid the reading difficulty. Cynthia said «I often talk with my mother only, to let her know that I have difficulties to read, sometimes she really want to help me [...] my father does not have time, he comes only on weekend because of his farm». Cynthia's mother argues that "we try to speak good english at home to correct her, but even if we do not speak "pigin" to them, when they are with their friends they can learn to speak it [...] as I said, I am a farmer and I don't have much time, her father too. [...] I myself did not go far with the school, but I will make effort to help her».

This situation can be observed with Paul, John and July. Paul argues «my problem is that I don't know how to read and my parents know about it since. My father often told me that if I don't make effort, I would leave school and go and sell with him, [...] sometimes, it is my brother who is in high school who teach me how to read at home when he has time.». Paul's mother on the interview recognizes the difficulties of her son and argues that «I myself did not have much time, I often return tired at night». According to John, the presence of parents do not impact on his reading difficulty and he recognize that sometimes, his father looks at his note books but he does not help him to read. The interview with his mother revealed as she said «despite of the fact that I am very busy by my farms, it is his uncle who sometimes monitors him or his father». The case of July show that, the absence of parent can be cause of the lack of communication and, even the level of education of her parent affect her reading difficulty. She stipulates that «my parents are at home only on Sunday. My mother does not know how to read and my father does not know how to read English».

Concerning the emotional support and an effective care, the study shows that some participants benefit from their mother support (Cynthia, Paul, and July). Cynthia's mother said «I often tell my daughter that if she can't read and write she cannot get success in hers studies». In the other hand, some parents reject the responsibility of the reading difficulty of student to the teacher. As July's mother said «when the child go to school, he must know how to read and write and I think that the teacher themselves do not do their job well for which they were trained». Some other parents reject the responsibility to the child himself as Cynthia's mother argues that «I think that it is because they are stubborn that they do not want to read, because she has reading book». John's mother said «the right way to encourage the child is to send him at school and buy him books. There are some children who don't have any book and don't have anybody to monitor them, but they succeed" In the same vein, July's mother stipulates that ushe (July) has no desire to learn to read, sometimes I flatter her to tell me why she do not want to read but she refuses to answer me, I am already tired about it»

Some participants of the study sometimes require help for other people to avoid their reading difficulty; as Paul (help of his brother), John (help of his uncle and his friends), July (help of tutor) and Cynthia (help of the neighbor' kids).

\section{Discussion}

The consideration of learning difficulty and disability of children is beneficial for their educational process, but further steps need to be taken to ensure school success and increase the performance levels of students. The appropriate reading and writing process can positively impact the school achievement and show an accurate picture of students' knowledge and skills. In contrary, reading disability can be link to the academic difficulty of a child and cause negative emotional feeling due to the experience of failure. As the study shows, most of the participants failed on some classes because of their reading disability (Cynthia, Paul, John).

To better solve the problem of reading disability, it is important to mention the role of school community with teachers first, but also the impact of parental support on this 
process. In this context, the child needs interaction with parents to build their language as a subject, and a positive parent-child relationship provides the foundation of children's learning success [9-11]. As the study shows, many participants of the study face difficulties to communicate with their parent and to try to cope with their reading difficulty (Cynthia, Paul, John and July) The participants of the study does not benefit for the encouragement of their father, but some other mentioned the minor support of their mother. The active participation of the students' mothers on this study shows their efforts in accompanying the participants on their process of overcome reading disability. But these efforts are suffering from a poor representation of the role of parent on the educational process of their child, a lack of knowledge, the occupational status of the parent that makes them to be constantly absent at home, the hostility and critical thinking about the children struggling to read, the poor educational level of the parent etc.

Despite the fact that, the parents are consider as the first educational actor of their children, and must implement a good quality and harmonious communication and parentchild relationship with their children, the study show that, the poor educational level of the parent and their bad representation of their role as educational aspect is concerned, and can negatively impact on the educational process of the student, and can be linked to their school failure.

For the future investigations, it is important to conduct a study on the impact of poor educational level of parent in the educational process of their children. Also, the clinical view of parents (mother and father) concerning the psychic meaning they are given to the educational and accompaniment process of their children is necessary to study. The study of siblings in the learning process or learning disability is also needed.

\section{Conclusion}

The aim of this study was to grasp the clinical view of specific learning disorder and the incidence of parental support on the reading disabilities of students. The study show that the lack of parental support impacts on student's level of reading disabilities. And this situation negatively affects the cognitive development of a student. The study show the importance of family factors and parental support on educational difficulties in the academic performance of student. It is therefore, important to think about a parental training session with collaboration of school community to help parents identify the learning difficulties of their children and to be more psychologically supportive with their children.

In this case, teachers, clinicians, mental health professionals, medical professionals and other educational specialist can put in place a collaborative approaches to avoid emotional discomfort in student facing learning difficulties, even in parent face with the reading disabilities of their children and to promote psychological well-being [21, 22].

\section{References}

[1] Bender, W. N. Learning disabilities: Characteristics, identification and teaching strategies. USA: Bacon, 2008.

[2] Kempe, C., Gustafson, S., et Samuelsson, S.. A longitudinal study of early reading difficulties and subsequent problem behaviors. Scand. J. Psychol. No 52, 2011, pp. 242-250.

[3] Bonifacci, P., Tobia, V., Marra, V., Desideri, L., Baiocco, R. et Ottavian, C. Rumination and emotional profile in children with specific learning disorders and their parents. International Journal of Environmental. Research and Public Health. Vol 17, No 389, 2020, pp 1-14.

[4] UNICEF. A Human Rights-Based Approach to Education. United Nations Children's Fund, 2005.

[5] American Psychiatric Association. Diagnostic and Statistical Manual of Mental Disorders, 5th Ed. Washington, DC: American Psychiatric Association, 2013.

[6] Ministry of Secondary education. Law n ${ }^{\circ} 98 / 004$ of 14 April 1998 to lay down guidelines for education in Cameroon, 1998.

[7] Vygotsky, L. Mind in society: The development of higher psychological processes. Cambridge: MA: Harvard University Press, 1978.

[8] Vygotsky, L. S. Thought and language. Cambridge, MA: MIT Press, 1985.

[9] Wagner, N. Impliquer les parents dans les séances d'orthophonie, de leur enfant ayant des troubles dyslexiques: Quel intérêt (s)?, Pour qui ?, Pour quoi faire ? Médecine humaine et pathologie: Université de Lorraine, 2013.

[10] Dawson, G., et Ashman, S. B. On the origins of a vulnerability to depression: The influence of the early social environment on the development of psychobiological systems related to risk for affective disorder. Minnesota Symposia on Child Psychology, No. 31, 2000, pp. 245-278.

[11] Brazelton, T. B. et Cramer, B. G. The earliest relationship: Parents, infants, and the drama of early attachment. Cambridge, MA: Perseus Books, 1990.

[12] Sahu, A., Bhargava, R., Sagar, R., Mehta, M. Perception of families of children with specific learning disorders: an exploratory study. Indian J Psychol Med. $\mathrm{N}_{0}$ 40, 2018, pp. 406-413.

[13] Tsuramaki, M., Sato, T., \&Yoshiaki, N. the effect of negatively worded measures of self-esteem on children, Social behavior and personality, No. 37, 2009, pp. 384-389.

[14] Senechal, M. Alphabétisation, langage et développement affectif.. Carleton University, 2009.

[15] Bergin, C. The parent-child relationship during beginning reading. University of Toledo, 2001.

[16] Mason, J. Qualitative researching, $2^{\text {nd }}$ edition, Sage Publication, London, UK, 2002.

[17] Alexander-Passe, N. How dyslexic teenagers cope: an investigation of self-esteem, coping and depression. Dyslexia. No. 12,2006 , pp. 256-275. 
[18] Mugnaini, D., Lassi, S., La Malfa, G., \& Albertini, G. Internalizing correlates of dyslexia. World J. Pediatr. No. 5, 2009, pp. 255-264.

[19] Germanò, E., Gagliano, A., \& Curatolo, P. Comorbidity of ADHD and Dyslexia. Dev. Neuropsychol. No. 35, 2010, pp. 475-493.

[20] Levy, F., Young, D. J., Bennett, K. S., Martin, N. C., \& Hay, D. A Comorbid ADHD and mental health disorders: are these children more likely to develop reading disorders? Atten. Defic. Hyperact. Disord. No. 5, 2013, pp. 21-28.
[21] Pham, A, V., Rivière, A. Specific learning disorders and ADHD: Current issues in Diagnosis across clinical and educational settings. Curr Psychiatry Rep, Vol 17, N0 38, pp. $1-7$.

[22] McDowell, M. Specific learning disability. Journal of paediatrics and child health division, N0 54, 2018, pp.10771083. 